\title{
Osmolarity: A hidden factor in Nanotoxicology
}

\author{
Saeid Moayyedi ${ }^{1}$, Omid Mashinchian ${ }^{2}$ and Rassoul Dinarvand ${ }^{3^{*}}$
}

\begin{abstract}
In the field of drug delivery, long circulating nanocarriers in the blood have many advantages such as targeted drug delivery and sustained release. Based on our current knowledge, evaluation of the effect of long circulating nanocarriers in the blood stream on osmolarity of plasma has not been reported before. In this study, osmotic pressure developed by some commercially available nanocarriers was estimated based on Van't Hoff equation. It is noteworthy that theoretically, nanocarriers do not have any significant effect on osmolarity of plasma. However, it is worth being evaluated experimentally in order to be taken into account in future studies.
\end{abstract}

Keywords: Nanocarriers, Drug delivery, Osmotic pressure

\section{Letters to the editor}

An osmosis phenomenon is the net movement of solvent (usually water) through a semipermeable membrane from a region of high water concentration (hypoosmolar solution) to a lower water concentration (hyperosmolar solution). Adding a solute to pure water decreases water concentration in the solution. In such conditons, water molecules can diffuse from a region of low solute concentration to one with a high solute concentration [1]. The effect of diverse solutes (i.e., molecules or ions) on osmolarity is depended on the number of dissolved particles in a solution, and is not correlated to their mass. Consequently, in an equal mass ratio, macromolecules (e.g., proteins, nucleic acids, polysaccharides) have much less influence on the osmolarity of a solution in comparison with their monomeric components. For example, a gram of a polysaccharide comprised of 1,000 glucose units and a milligram of glucose have the identical effect on osmolarity. In order to prevent of an enormous increase in osmolarity inside the storage cell (e.g., hepatocyte), the fuel is stored in the form of polysaccharide (i.e., starch or glycogen) rather than glucose or other simple sugars by the cells [2].

\footnotetext{
* Correspondence: dinarvand@tums.ac.ir

${ }^{3}$ Nanotechnology Research Centre, Faculty of Pharmacy, Tehran University of Medical Sciences, Tehran, Iran

Full list of author information is available at the end of the article
}

Similarly, increasing osmolarity of plasma leads to net reabsorption of fluid from interstitial fluid into the capillaries rather than net filtration. On the other hand, increasing osmolarity of plasma leads to antidiuretic hormone secretion. Osmolarity of plasma is approximately $300 \mathrm{mOsm} / \mathrm{L}$. Change as small as $1 \%$ in osmolarity of plasma leads to increasing antidiuretic hormone secretion significantly. This hormone decreases the excreted volume of fluid by the kidneys. Ultimately, Due to increased blood volume, arterial pressure increases $[1,3]$.

In the field of drug delivery, long circulating nanocarriers in the blood have many advantages such as targeted drug delivery and sustained release [4-6]. Until now, numerous studies have been performed in the Nanotoxicology [7, 8]. Nevertheless, evaluation of the effect of long circulating nanocarriers in the blood stream on osmolarity of plasma has not been reported before.

For this reason, osmotic pressure developed by some commercially available nanocarriers per $1 \mathrm{~L}$ of plasma estimated based on Van't Hoff equation. Data shown in Table 1 illustrates that theoretically, nanocarriers do not have any significant effect on osmolarity of plasma. However, it is worth being evaluated experimentally in order to be taken into account in future studies. 
Table 1 Estimation of osmotic pressure developed by some commercially available nanocarriers per $1 \mathrm{~L}$ of plasma

\begin{tabular}{lll}
\hline Trade name & Osmotic pressure $(\mathrm{mm} \mathrm{Hg})$ & Osmolarity $(\mathrm{mOsm} / \mathrm{L})$ \\
\hline Doxil & $7.0 \times 10^{-5}$ & $4.0 \times 10^{-6}$ \\
Abraxane & $2.0 \times 10^{-2}$ & $1.0 \times 10^{-3}$ \\
AmBisome & $3.2 \times 10^{-4}$ & $1.7 \times 10^{-5}$ \\
Marqibo & $3.2 \times 10^{-5}$ & $1.7 \times 10^{-6}$ \\
DepoCyt & $3.0 \times 10^{-5}$ & $2.3 \times 10^{-6}$ \\
\hline
\end{tabular}

\section{Competing interests}

The authors declare that they have no competing interests.

\section{Authors' contributions}

SM conceived of the study and participated in its design and carried out the calculation. OM participated in design of study and drafted the manuscript. $\mathrm{RD}$ participated in design and supervision of study and revised the manuscript. All authors read and approved the final manuscript.

\section{Author details}

'Department of Medical Nanotechnology, School of Advanced Technologies in Medicine (SATiM), Tehran University of Medical Sciences, Tehran, Iran. ${ }^{2}$ Institute of Bioengineering, School of Life Sciences, Ecole Polytechnique Fédérale de Lausanne (EPFL), Lausanne, Switzerland. ${ }^{3}$ Nanotechnology Research Centre, Faculty of Pharmacy, Tehran University of Medical Sciences, Tehran, Iran

Received: 2 February 2016 Accepted: 9 March 2016

\section{Published online: 22 March 2016}

\section{References}

1. Hall JE. Guyton and Hall Textbook of Medical Physiology. 12rd ed. Philadelphia: Elsevier Health Sciences; 2010.

2. Nelson DL, Lehninger AL, Cox MM. Lehninger principles of biochemistry. 5rd ed. London: Macmillan; 2008.

3. Levy MN, Berne RM, Koeppen BM, Stanton BA. Berne \& Levy physiology. 6rd ed. St. Louis: Mosby; 2010.

4. Bae YH, Park K. Targeted drug delivery to tumors: myths, reality and possibility. J Control Release. 2011;153:198.

5. Torchilin V. Tumor delivery of macromolecular drugs based on the EPR effect. Adv Drug Deliv Rev. 2011;63:131-5.

6. Cho K, Wang X, Nie S, Shin DM. Therapeutic nanoparticles for drug delivery in cancer. Clin Cancer Res. 2008;14:1310-6.

7. Sharifi S, Behzadi S, Laurent S, Forrest ML, Stroeve P, Mahmoudi M. Toxicity of nanomaterials. Chem Soc Rev. 2012;41:2323-43.

8. Li X, Liu W, Sun L, Aifantis KE, Yu B, Fan Y, et al. Effects of physicochemical properties of nanomaterials on their toxicity. J Biomed Mater Res A. 2015; 103:2499-507.

\section{Submit your next manuscript to BioMed Central} and we will help you at every step:

- We accept pre-submission inquiries

- Our selector tool helps you to find the most relevant journal

- We provide round the clock customer support

- Convenient online submission

- Thorough peer review

- Inclusion in PubMed and all major indexing services

- Maximum visibility for your research

Submit your manuscript at www.biomedcentral.com/submit
Biomed Central 